\title{
Krónikus orofacialis fájdalmak
}

\author{
Fehér Gergely dr. ${ }^{1,7}$ - Nemeskéri Zsolt ${ }^{2}$ - Pusch Gabriella ${ }^{3}$ \\ Zádori Iván $^{2}$ - Bank Gyula ${ }^{5}$ - Gurdán Zsuzsanna ${ }^{6}$ - Mészáros János ${ }^{1}$ \\ Mák Kornél ${ }^{1}$ - Tibold Antal ${ }^{1}$ - Komoly Sámuel dr. ${ }^{3}$ \\ ${ }^{1}$ Pécsi Tudományegyetem, Általános Orvostudományi Kar, Klinikai Központ, \\ Foglalkozás-egészségügyi és Munkahigiénés Központ, Pécs \\ ${ }^{2}$ Pécsi Tudományegyetem, Kultúratudományi, Pedagógusképző és Vidékfejlesztési Kar, \\ Kultúra- és Társadalomtudományi Intézet, Pécs \\ ${ }^{3}$ Pécsi Tudományegyetem, Általános Orvostudományi Kar, Klinikai Központ, Neurológiai Klinika, Pécs \\ ${ }^{4}$ Pécsi Tudományegyetem, Általános Orvostudományi Kar, Klinikai Központ, I. Belgyógyászati Klinika, Pécs \\ ${ }^{5}$ Kecskeméti Kórház, Krónikus Belgyógyászati Osztály, Kecskemét \\ ${ }^{6}$ Pécsi Tudományegyetem, Általános Orvostudományi Kar, Fogorvostudományi Szak, Klinikai Központ, \\ Fogászati és Szájsebészeti Klinika, Pécs \\ ${ }^{7}$ EÜ-MED Kft., Neurológiai Szakrendelés, Komló
}

\begin{abstract}
Az orofacialis fájdalom egy gyújtőszó, mely sokféle kórképet takarhat a gyulladásos kórképektől kezdve a neuropathiás fájdalomig. Maga a kórkép nem ritka, akár a populáció 7\%-át érintheti. Sokszor maguk a betegek sem tudják, hogy panaszokkal fogászhoz vagy más szakemberhez forduljanak. A régió sok szakma határterületét képezi (fogászat, fülészet, szemészet, neurológia stb.), így nem meglepő, hogy egy-egy beteg akár 6-7 specialistánál megfordul. Öszszefoglaló közleményünk célja, hogy áttekintést adjunk a krónikus orofacialis fájdalommal járó kórképek diagnózisáról, az esetleges differenciáldiagnosztikai lehetőségekról és kezelési módokról.
\end{abstract}

Orv Hetil. 2019; 160(27): 1047-1056.

Kulcsszavak: arcfájdalom, krónikus fájdalom, neuropathiás fájdalom, depresszió, diagnózis, kezelés, fájdalom-munkacsoport

\section{Chronic orofacial pain}

Orofacial pain is the common name of a variety of disorders from inflammatory diseases to neuropathic pain syndromes. This condition is quite common, it may involve $7 \%$ of the whole population. Patients (and doctors) are not aware of the origin of their complaints, therefore initial management falls among the variety of healthcare professionals. The aim of our review was to summarize the current evidence of chronic orofacial pain including diagnosis, management and pitfalls.

Keywords: facial pain, chronic pain, neuropathic pain, depression, diagnosis, treatment, multidisciplinary team

Fehér G, Nemeskéri Zs, Pusch G, Zádori I, Bank Gy, Gurdán Zs, Mészáros J, Mák K, Tibold A, Komoly S. [Chronic orofacial pain]. Orv Hetil. 2019; 160(27): 1047-1056.

(Beérkezett: 2019. február 1.; elfogadva: 2019. március 8.)

\section{Rövidítések}

$\mathrm{ACE}=$ (angiotensin-converting enzyme) angiontezinkonvertáló enzim; COMT = katechol-O-metiltranszferáz; CRP = C-reaktív protein; $\mathrm{CT}=($ computed tomography $)$ komputertomográfia; $\mathrm{ESR}=($ erythrocyte sedimentation rate $)$ erythrocytaszedimentációs ráta (vörösvérsejt-süllyedés); GABA = (gamma-aminobutyric acid) gamma-amino-vajsav; $\mathrm{MAO}=$ monoamin-oxidáz; $\mathrm{MR}=$ (magnetic resonance $)$ mágneses re- zonancia; $\mathrm{NMDA}=\mathrm{N}$-metil- $\mathrm{D}$-aszparaginát $\mathrm{PAG}=($ periaqueductal gray) periaquaeductalis szürkeállomány; rtg. = röntgen; SCN9A = (voltage-gated sodium-channel IX $\alpha$ subunit) feszültségfüggő káliumcsatorna IX $\alpha$ alegysége; SNRI = (serotonin noradrenaline reuptake inhibitor) szerotonin- és noradrenalin-újrafelvételt gátló szer; SSRI $=$ (selective serotonin reuptake inhibitor) szelektív szerotonin-újrafelvételt gátló szer; SUNA = short-lasting unilateral neuralgiform headache 
attacks with cranial autonomic feautures; SUNCT = short-lasting unilateral neuralgiform headache attacks with conjunctival injection and tearing; TCA = triciklusos antidepresszáns; $\mathrm{UH}=$ ultrahang

\section{Orofacialis fájdalmak}

Az orofacialis fájdalom egy gyưjtőszó, mely sokféle kórképet takarhat a gyulladásos kórképektól kezdve a neuropathiás fájdalomig. Maga a kórkép nem ritka, akár a populáció 7\%-át érintheti [1]. Sokszor maguk a betegek sem tudják, hogy panaszaikkal fogászhoz vagy más szakemberhez forduljanak. A régió sok szakma határterületét képezi (fogászat, fülészet, szemészet, neurológia stb.), így nem meglepő, hogy egy-egy beteg akár 6-7 specialistánál megfordul [2]. Mindazonáltal a betegeknek csupán a negyede kap a számukra (és alapbetegségüknek), valamint az aktuális ajánlásoknak is megfelelő ellátást [2].

Alapvetően szemléletmódváltás szükséges a krónikus fájdalmak kezelésében. Krónikus fájdalomról beszélünk, ha a panasz több mint 3 hónapja fennáll [3]. Míg az akut fájdalom (például egy vágott seb vagy bokaficam) általában spontán, mindenféle szövődmény nélkül megszünik, krónikus fájdalom esetében centrális és perifériás idegrendszeri szenzitizációhoz, ső́t egyes agyi struktúrák - például a thalamus, a dorsolateralis praefrontalis cortex - elvékonyodásához vezet [3]. Kiemelendő, hogy a krónikus fájdalom az esetek döntő többségében részben neuropathiás eredetú, így szakítanunk kell azzal a szemlélettel, hogy részletes (és sokszor értelmetlen) kivizsgálási procedúrák történjenek a fájdalom szervi okának kiderítésére. A neuropathiás fájdalom az idegrendszer károsodása miatt alakul ki (lásd fenn), tehát nincs szomatikus-szervi károsodás a fájdalom hátterében, illetőleg a kivizsgálások során talált eltérések általában mellékleletek (példának okáért nyaki borda keresése vállövi fájdalmak, karzsibbadás esetében, mely a populáció akár 5\%ában előfordulhat fejlődési variánsként) $[3,4]$.

Ráadásul az orofacialis fájdalom krónikus formái nagyon gyakran szövődnek különböző pszichiátriai komorbiditásokkal, és a pszichiátriai alapbetegség is hajlamosít fájdalomszindrómák kialakulására. Szakirodalmi adatok alapján ezen betegek mintegy tizede kerül referálásra pszichiáterhez, neurológushoz vagy egyéb fájdalomspecialistához, a többség többszöri (és gyakran felesleges) mütéti és egyéb beavatkozásokon esik át érdemi állapotjavulás nélkül [4].

Összefoglaló közleményünk célja, hogy áttekintést adjunk a krónikus orofacialis fájdalommal járó kórképek diagnózisáról, az esetleges differenciáldiagnosztikai lehetőségekről és kezelési módokról.

\section{Kivizsgálási lehetőségek}

Első körben mindenképpen fontos tisztázni a fájdalom jellegét, időtartamát, fennállásának idejét, kiváltó és eny-

1. táblázat |A neuropathiás fájdalom tünetei és a vizsgálati lehetőségek

\begin{tabular}{|c|c|c|}
\hline \multicolumn{3}{|l|}{ Negatív szimptómák } \\
\hline Név & Tünet & Kimutatás \\
\hline Hypoaesthesia & Nem fájdalmas érzetek csökkenése & A terület érintése ecsettel \\
\hline Pallhypoaesthesia & Vibrációérzet csökkenése & Hangvilla \\
\hline Hypoalgesia & Csökkent fájdalomérzés & Tűszúrás (fogpiszkáló a gyakorlatban) \\
\hline Thermohypoaesthesia & Csökkent hőérzékenység & $\begin{array}{l}\text { Hideg és meleg tárgyak érintése (például } 10 \text { és } \\
45^{\circ} \mathrm{C} \text { ) }\end{array}$ \\
\hline \multicolumn{3}{|l|}{ Spontán érzetek/fájdalmak } \\
\hline Név & Tünet & Kimutatás \\
\hline Paraesthesia & $\begin{array}{l}\text { Nem fájdalmas érzetek (zsibbadás, zsiborgás, hangyamá- } \\
\text { szásérzés) }\end{array}$ & $\begin{array}{l}\text { Epizódok száma } \\
\text { Súlyosság }(0-10)\end{array}$ \\
\hline Paroxysmalis fájdalom & $\begin{array}{l}\text { Fájdalmas, másodpercekig (rövid ideig) tartó villanyozás- } \\
\text { szerú érzés }\end{array}$ & $\begin{array}{l}\text { Kiváltó ok } \\
\text { Terület kiterjedése }\left(\mathrm{cm}^{2}\right)\end{array}$ \\
\hline Felületi fájdalom & Folyamatos maró-égő fájdalomérzet & \\
\hline \multicolumn{3}{|l|}{ Kiváltott fájdalom } \\
\hline Név & Tünet & Kimutatás \\
\hline Mechanikus dinamikus allodynia & Normálisan nem fájdalmas inger fájdalmat vált ki & Bőr érintése finom ecsettel \\
\hline Mechanikus statikus allodynia & Normálisan nem fájdalmas nyomás fájdalmat vált ki & Diszkrét nyomás a bőr felületén \\
\hline Mechanikus szúrási hyperalgesia & $\begin{array}{l}\text { Szúró (de normális körülmények között nem fájdalmas) } \\
\text { inger fájdalmat vált ki }\end{array}$ & Bőr fogpiszkálóval történő vizsgálata \\
\hline $\begin{array}{l}\text { Időbeli összeadódás } \\
\text { (temporalis szummáció) }\end{array}$ & Ismétlődő ingerlés fokozódó fájdalmat generál & Repetitív szúrások fogpiszkálóval \\
\hline Hideg allodynia & Normálisan nem fájdalmas hideginger fájdalmat vált ki & Bőr érintése $20^{\circ} \mathrm{C}$-os tárggyal \\
\hline Meleg allodynia & Normálisan nem fájdalmas meleginger fájdalmat vált ki & Bőr érintése $40^{\circ} \mathrm{C}$-os tárggyal \\
\hline $\begin{array}{l}\text { Mechanikus mély szomatikus } \\
\text { allodynia }\end{array}$ & Normálisan nem fájdalmas nyomásérzet fájdalmat vált ki & Ízületre vagy izomra gyakorolt finom nyomás \\
\hline
\end{tabular}


hítő tényezőit, továbbá hogy milyen esetleges egyéb tünetekkel jár együtt (például láz, fogyás, látászavar stb.; lásd később). A szomatikus fájdalmon kívül, különösen krónikussá váló fájdalom esetén, mindig gondoljunk neuralgiform/neuropathiás karakterű kórképekre is, melyek teljesen más kezelési stratégiát igényelnek.

Elöljáróban elmondható, hogy a hirtelen, éles, égőnyilalló, villámcsapásszerü, rövid ideig (maximum 1-2 perc) és ismétlődő vagy hosszabb ideig folyamatosan fennálló égő/perzselő/szúró fájdalom, hőre-rágásra, egyéb stimulusra provokálódó/rosszabbodó fájdalom igen komolyan felveti a neuropathiás fájdalom lehetőségét, mely alapvetően más megközelítést és kezelést igényel [3-5] (1. táblázat). Ma már vannak standardizált kérdőívek, melyek a neuropathiás fájdalom detektálására alkalmasak, mint például a DN4-kérdőív, mely magyarul is elérhető $[5,6]$. Léteznek komplexebb felmérést lehetővé tévő tesztek is, de ezek sajnos magyar nyelven még nem érhetők el [7].

A betegeknél első körben részletes laborvizsgálatok is történjenek, lehetőleg a süllyedés, C-reaktív protein (CRP), pajzsmirigyfunkció és hemoglobin $\mathrm{A}_{\mathrm{lc}}$ meghatározása is legyen benne (például a burning mouth syndrome - lásd később - akár a cukorbetegség, pajzsmirigybetegség első tünete is lehet, emelkedett a süllyedés és a CRP arteritis temporalisban, stb.).

A fogászati röntgenfelvétel kihagyhatatlan része a vizsgálatnak, a dentalis patológia kimutatásában igen nagy érzékenységü, esetlegesen fiberoszkópos vizsgálatokkal kiegészítve. Az arckoponyaröntgen találati aránya alacsony, például sinusitis esetében csupán 70\%-ban diag- nosztikus, és sok a hamis fals pozitív lelet aránya is (továbbá megemlítendő, hogy fejtrauma esetében a koponyaröntgen elvégzése gyakorlatilag felesleges, igen alacsony találati aránya miatt). Sinusitis, töréses háttér eshetősége esetén koponya-CT-vizsgálat javasolt, de a választandó képalkotó módszer a koponya-MR-vizsgálat [7]. Egyes esetekben, például arteritis temporalis lehetősége esetén, az ultrahang (temporalis ultrahang) diagnosztikus jelentőségû lehet (ún. halo-jel), de szerepe a fájdalmas kórképek kivizsgálásában limitált [8].

\section{Dentogén fájdalom}

A fogászati eredetú fájdalom az egyik leggyakoribb oka az orofacialis fájdalmaknak. Fontos, hogy a fogászati fizikális vizsgálaton kívül legalább fogászati röntgen is készüljön, az esetleges felesleges beavatkozásokat elkerülendő. Az akut fogászati kórképek tárgyalása meghaladja cikkünk kereteit, csak a differenciáldiagnosztikai szempontból fontos krónikus fájdalmakat említjük. Mindenesetre megemlítendő, hogy a fogászati kórképek döntő többségében a fog nyomásra/kopogtatásra érzékeny, és képalkotón kórjelző eltérések ábrázolódnak [8].

A repedt fog szindróma („cracked tooth syndrome”) inkomplett fogtörést takar, mely döntően a hátsó molaris fogakat érinti, és gyakran a gyökércsatornát is eléri. A fájdalom kisugárzása miatt gyakran nehéz az eredetét is tisztázni. A beteg általában leüléskor megjelenő/roszszabbodó fájdalomra panaszkodik, melyet hideg-meleg ingerek, rágás provokál/ront. A fog nyomásra nem fel-

2. táblázat |A neuropathiás fájdalom kezelésében használatos szerek

\begin{tabular}{|c|c|c|c|c|c|}
\hline Gyógyszercsoport & Evidenciaszint & Hatásmechanizmus & Kerülendő & Főbb mellékhatások & Egyéb előnyök \\
\hline $\begin{array}{l}\text { Triciklusos antidepresz- } \\
\text { száns (TCA) }\end{array}$ & Erős & $\begin{array}{l}\text { Szerotonin- és noradrenalin- } \\
\text { újrafelvétel gátlása, } \\
\text { Na-csatorna-blokkoló hatás, } \\
\text { antikolinerg effektus }\end{array}$ & $\begin{array}{l}\text { Posztinfarktusos } \\
\text { állapot, arrhythmiák, } \\
\text { glaucoma }\end{array}$ & $\begin{array}{l}\text { Szedáció, } \\
\text { antikolinerg } \\
\text { mellékhatás } \\
\text { (szájszárazság stb.) }\end{array}$ & $\begin{array}{l}\text { Antidepresszáns hatás, } \\
\text { alvásjavító effektus }\end{array}$ \\
\hline $\begin{array}{l}\text { Szerotonin- és } \\
\text { noradrenalin-újrafelvé- } \\
\text { telt gátló szerek } \\
\text { (SNRI-k) }\end{array}$ & Erős & $\begin{array}{l}\text { Szerotonin- és noradrenalin- } \\
\text { újrafelvétel gátlása }\end{array}$ & $\begin{array}{l}\text { Máj- és veseelégtelen- } \\
\text { ség, alkoholizmus, } \\
\text { súlyos szívbetegség }\end{array}$ & Hányinger & $\begin{array}{l}\text { Antidepresszáns, } \\
\text { szorongásoldó }\end{array}$ \\
\hline Gabapentin & Erős & $\begin{array}{l}\text { Glutamát, noaradrenalin } \\
\text { és P-anyag szekréciójának } \\
\text { gátlása a feszültségfüggó } \\
\text { Ca-csatornákon keresztül }\end{array}$ & Veseelégtelenség & $\begin{array}{l}\text { Szedáció, szédülés, } \\
\text { ödéma }\end{array}$ & $\begin{array}{l}\text { Nem ismert klinikailag } \\
\text { szignifikáns gyógyszer- } \\
\text { interakció }\end{array}$ \\
\hline Pregabalin & Erős & Lásd fenn & Lásd fenn & Lásd fenn & $\begin{array}{l}\text { Lásd fenn, plusz } \\
\text { alvásjavító és } \\
\text { szorongásoldó effektus }\end{array}$ \\
\hline Opiátok & $\begin{array}{l}\text { Erôs/ } \\
\text { mérsékelt }\end{array}$ & $\begin{array}{l}\mu \text {-receptor-agonizmus, } \\
\text { szerotonin- és noradrenalin- } \\
\text { újrafelvétel gátlása }\end{array}$ & $\begin{array}{l}\text { Abúzusra hajlamos } \\
\text { beteg, pszichés } \\
\text { instabilitás, SNRI/ } \\
\text { SSRI, illetve TCA mellé } \\
\text { adva szerotoninszind- } \\
\text { róma megnövekedett } \\
\text { eshetósége }\end{array}$ & $\begin{array}{l}\text { Hányinger, } \\
\text { hányás, szédülés, } \\
\text { székrekedés }\end{array}$ & Gyors hatás \\
\hline
\end{tabular}

SNRI = szerotonin- és noradrenalin-újrafelvételt gátló szer; SSRI = szelektív szerotonin-újrafelvételt gátló szer; TCA = triciklusos antidepresszáns 
tétlenül érzékeny. A fogászati röntgen negatív is lehet, ilyenkor fiberoszkópos vizsgálat vagy arckoponya-CT elvégzése segít a diagnózisban [9].

A fogbélfájdalom (pulpáris fájdalom) esetében változó intenzitású fájdalom lép fel, mely hőre, kémiai vagy mechanikai behatásokra egyértelmúen provokálódik, de nem neuropathiás/neuralgiform karakterű. Nyomás/ kopogtatásérzékenység döntően nincs, de rtg.-en diagnosztikus eltérések láthatók [10].

Az atipusos fogfájdalom (atipusos odontalgia) döntően a negyedik évtizedtől jelentkezik, női túlsúllyal $[10,11]$. Ez a fogra (íny, fogágy) lokalizálódó, égő jellegú, hasogató/hasító komponensekkel jelentkező fájdalom, mely időnként vándorolhat is, továbbá ritkán akár az egész alsó, illetve felső állkapocsra kiterjedhet. Sajnos általában extenzív vizsgálatok és többszörös fogászati beavatkozás történik, érdemi állapotjavulás nélkül. Egyrészt a fájdalom jellege, másrészt a nem fájdalmas ingerek (például érintés) által kiváltott paradox fájdalomérzet hívja fel a figyelmet a kórkép neuropathiás jellegére [11]. Terápiájában a neuropathiás fájdalom kezelési útmutatói az irányadók (részletesen lásd később) (2. táblázat).

\section{Szájüregi fájdalom}

A szájüregi fájdalom szintén többféle kórképet magában foglaló gyüjtőnév [12]. A kórképek többségére igaz, hogy krónikus fájdalmat tart fenn, de már inspekciókor diagnózishoz vezető típusos eltérések ábrázolódnak (ulceratio, lichen planus, gyulladásos eltérések) [11, 12].

A ritkán előforduló nyálkövesség (sialolithiasis) általában evéskor-ivás után (postprandialis) provokálódik, alacsony intenzitású fájdalmat és nyomást/duzzanatérzést okoz. Az esetek 80-90\%-ában a submandibularis nyálmirigy érintett, a többi esetben a parotis, továbbá a beteg anamnézisében többszörös sialoadenitis szerepelhet [13]. Ultrahangvizsgálat itt segít a diagnózisban, illetve natív koponya-CT a nyálkövek kimutatásában, melyek döntően kalcium-karbonátot tartalmaznak [13].

Az égöszáj-szindróma (burning mouth syndrome) ritka, de kellemetlen karakterü fájdalommal járó betegség. Döntően idősebb (a 6-7. évtizedben járó) nőket érint, akik anamnézisében általában pszichiátriai komorbiditás is szerepel, a leggyakrabban generalizált szorongás, illetőleg depresszió. A szájüreg, ezen belül is elsősorban a nyelv elülső részének égő érzésével járó kórkép, melyet szájszárazság, ízérzéscsökkenés és fémes érzés kísérhet. Mucosalis, illetőleg nyálválasztási abnormalitás nem detektálható [12]. Első körben kizárandó a gyógyszermellékhatás (leggyakrabban ACE-gátló, illetve SSRI - elsősorban paroxetin), illetőleg a metabolikus faktorok szerepe (pajzsmirigy-, illetve cukorbetegség, praediabetes). Ritkábban Sjögren-szindróma, illetőleg vitamin- és nyomelemhiány, de vékonyrost-neuropathia is állhat a háttérben $[12,13]$.

Tekintettel a betegek kórelőzményében szereplő komorbiditásra, sokan tisztán pszichiátriai eredetűnek tart- ják ezt a fájdalmat, de mind a nyelv fájdalomérzékelő receptoraiban, mind az agyi fájdalom feldolgozásáért felelős struktúrákban kimutatható változások jönnek létre, a neuropathiás fájdalmakhoz hasonlóan [14]. Lokális kapszaicin- vagy alacsony intenzitású lézeres terápia, illetőleg klonazepám- vagy alfa-liponsavas kezelés jöhet még szóba a neuropathiás fájdalom csillapítására alkalmas szerek mellett esetlegesen [15]. A kognitív terápia is jó hatásúnak bizonyulhat [13-15].

Igen ritka kórkép a nyelv-garat idegzsába (glossopharyngeus neuralgia), előfordulása $0,5-1 / 100000$, női túlsúllyal [16]. Paroxysmalis, másodpercektől akár 1-2 percig terjedő égő, éles, villámcsapásszerü fájdalommal jár, mely a nyelv és a torok hátsó részét, illetve az állkapocstájékot érinti, akár fülbe sugárzóan. Nyelés, rágás, evés, ivás, esetlegesen állkapocsnyitás, fogmosás, a mandibulaszeglet bőrének érintése is provokálhatja. Van, aki diagnosztikusnak tartja, ha 10\%-os lidokainnal a garat hátsó falát és a tonsillák környékét befújva a fájdalom megszúnik. A kórkép döntően idiopathiás, igen ritkán áll egyéb kórkép a háttérben (koponyaalapi folyamat, törés, cerebellopontin, illetve pharynxtumorok stb.) [16]. Karbamazepin, triciklusos antidepresszánsok, esetlegesen gamma-amino-vajsav-analóg (GABA-erg) szerek hatékonyak lehetnek (gabapentin, pregabalin) $[8,16]$.

\section{Arcfájdalmak}

Az arcfájdalmak túlnyomó többségét a sinusitisek adják. Akut formában általában könnyen felismerhetők, hiszen a fájdalom mellett lázzal, purulens orrváladékozással és felső légúti fertőzés tüneteivel járnak. Krónikus formában néha nehezebb a kórisme, és igen kellemetlen karakterú fájdalmat tudnak okozni. A fájdalom különböző helyekre terjedhet ki, sinus frontalis esetén frontoorbitalisan, a sinus maxillaris gyulladása pedig a felső ajakba, szájpadba, felső fogsorba sugározhat, míg sinus sphenoidalis esetében a homlokba, temporalis régióba, fejtetóbe terjedhet a fájdalom. Általában rhinorrhoeával, szaglásés ízérzészavarral járnak, döntően sem fény- és hangérzékenység, sem pedig heves vegetatív tünetek nincsenek, mint a migrén esetében. Mozgásra, előrehajláskor provokálódik általában a fájdalom. Koponya-képalkotó (CT-, illetve MR-) vizsgálat segít a kórképek elkülönítésében; a rutinrtg. gyakran félrevezető eredményt ad, diagnosztikus érzékenysége csekély $[8,10,11]$.

Talán az egyetlen, szélesebb körben is ismert neuropathiás fájdalom az arcidegzsába (trigeminusneuralgia), mely egyben az egyik leggyakoribb krónikus arcfájdalom [17]. Előfordulása idiopathiás formában 3-6/100 000 fó, a betegek 70\%-a 60 évnél idősebb. A kórképet villámcsapásszerú, éles, másodpercekig tartó fájdalomrohamok jellemzik, melyeket rágás, nyelés, érintés provokálhat. A kórkép jellemzően a nervus (n.) trigeminus II., illetve III. ágának érintettségével jár, unilateralis megjelenésû. Néha atípusos érzészavar az arcon jelentkezhet, de a fájdalmon kívül egyéb neurológiai tünetek megjelenése 
azonnal vesse fel más etiológia lehetőségét, akár csak az I. ág (homloktájék) érintettségét, illetve bilaterális érintettséget is. Típusos esetben is érdemes célzott MR-vizsgálat elvégzése neurovascularis kompresszió kimutatására. Ezekben az esetekben egy aberráns érkacs komprimálja a trigeminusgyököt, ami szekunder, de megjelenésében típusos trigeminusneuralgiát okoz. Az érkompresszió mikrosebészeti módszerrel megoldható [18].

Fiatal beteg esetében mindig merüljön fel a sclerosis multiplex mint oki tényező, illetve atípusos tünettan esetében is gondoljunk szekunder etiológiára (például a koponyabázist érintő daganat) [19]. Idiopathiás kórkép kezelésében a karbamazepin és az oxkarbazepin (ez utóbbi gyógyszer hazánkban a kórkép kezelésére azonban nem törzskönyvezett - off-label) jön elsősorban szóba, ezek hatástalansága esetén baklofén, lamotrigin vagy pimozid megpróbálható [17]. Fontos kiemelni, hogy noha karbamazepin alkalmazása számos neuropathiás kórképben történik (postherpeses neuralgia, post-stroke fájdalom stb.) hazánkban, a trigeminus- (és esetlegesen egyéb arc/fej) neuralgiák (lásd később) kivételével erre egyértelmű indikáció nincs, hatékonysága ezekben a kórképekben messze nem kielégítő, mint azt ismételt Cochrane-metaanalízisek is alátámasztják [20]. Trigeminusneuralgiában gyakorlati tapasztalat, hogy a karbamazepin retard készítményról gyorsan felszívódóra váltva az addig észlelt „karbamazepinrezisztencia” megszűnik, és a beteg fájdalma kontrollálhatóvá válik. Egyre több bizonyíték van továbbá arra, hogy (hasonlóan, mint krónikus migrén esetében) a botulinustoxin-kezelés hatékony lehet ebben a kórképben is [21].

A szakirodalom megkülönböztet ún. poszttraumás arcidegzsábát (poszttraumás trigeminusneuralga) is, mely döntően a trigeminusganglion (Gasser-ganglion) körül történő ablatív mútétek után alakulhat ki, de ritkán lehet traumás eredetű is [8]. Ez igen kellemetlen, erôs emocionális színezettel is járó fájdalom, mely a trigeminus mindhárom ágát érinti (a betegek égô, hangyamászásszerü fájdalomról számolnak be). Szintén kialakulhat fogászati beavatkozások után hasonló karakterü fájdalom az érintett ideg lefutásának megfelelően [11]. Ilyen esetekben a neuropathiás fájdalom kezelésének irányelvei az útmutatók, illetve a kognitív terápia is hatékonynak bizonyulhat $[8,11]$.

A trigeminusneuralgia differenciáldiagnózisába (többek között) beletartozik az atipusos arcfájdalom is. Ez folyamatos égő/nyomó érzéssel, időnként fájdalomkiugrásokkal járó kórkép, mely döntően középkorú nőket érint (míg a trigeminusneuralgia idősebb korosztályt érint, és a fájdalom nem konstans, hanem villámcsapásszerü érzéssel jár) [22]. A fájdalom döntően a mandibula lefutásának megfelelő, a nyakba is sugározhat, de egyéb prezentáció sem ritka. Az esetek 70-80\%-ában megelőzően fogászati beavatkozás történt. Szintén gyakori a megelőző/konkomittáns pszichiátriai megbetegedés, mint az égőszáj-szindróma esetében, de voxelalapú mor- fometriás MR-vizsgálatok a neuropathiás fájdalommal járó kórképekhez hasonló intracranialis strukturális eltéréseket írtak le, azaz a fájdalom megfelel a neuropathiás fájdalomnak, és ilyen irányú kezelése javasolt [11].

Igen ritka a csupán az arca lokalizálódó migrén (facialis migrén, más néven neurovascularis orofacialis fájdalom), mely az arc alsó részére lokalizálódó (döntőn $\mathrm{V} / 2$, illetve $\mathrm{V} / 3$ ) migrénes karakterú fájdalmat jelent (féloldali, lüktető fájdalom, fény- és hangérzékenységgel és/ vagy hányingerrel/hányással). Önálló entitásként való létezése megkérdőjelezhető, ám egyes adatok szerint a migrénesek 9\%-ában ilyen tünetek is jelentkezhetnek $[23,24]$. Kezelésében a migrénes fejfájás kezelésére vonatkozó irányelvek az útmutatók (3. táblázat).

\section{Temporomandibularis fájdalmak}

Az utóbbi évek kutatásai hívták fel a figyelmet a temporomandibularis izületi diszfunkció okozta arcfájdalom (temporomandibularis dysfunctio) jelentőségére (melyet myofascialis arcfájdalomnak is neveznek) [25]. A temporomandibularis dysfunctio szakirodalmi adatok alapján a krónikus derékfájás után a leggyakoribb musculoskeletalis fájdalom. A fájdalom az állkapocs izmait érinti, továbbá a masseter vagy a temporalis izomzat nyomásával provokálható/reprodukálható $[7,25]$. A temporomandibularis ízület mozgásai korlátozottak, szájnyitáskor/ mozgáskor crepitatio, illetve egyéb zörejek hallhatók [25-27]. Sok esetben (mint krónikus derékfájásnál) degeneratív eltérések, porcrendellenességek, ízületi eltérések detektálhatók, de ezek önmagukban nem magyarázzák a fájdalmat. Egyre több a bizonyíték arra, hogy ez a kórkép is a krónikusfájdalom-szindrómák/neuropathiás fájdalmak közé tartozik, mint a fibromyalgia, a migrén vagy a derékpanaszok, és a későbbiekben talán ezen kezelési irányelvek lesznek az irányadók a betegek gyógyításában [28]. Jelenleg bizonyos akupunktúrás technikák és repozíciós sebészeti eljárások esetlegesen hatékonyak lehetnek $[26,27]$.

\section{Óriássejtes arteritis}

$\mathrm{Az}$ arteritis temporalis temporalis hangsúlyú fejfájást okoz, skalpérzékenységgel, mely akár hetekkel megelőzheti a fájdalmat. A betegek döntően 50 év felettiek, női túlsúllyal. Patognomikus, noha nem minden esetben lép fel döntően rágáskor jelentkező/rosszabbodó fájdalom ( "rágási claudicatio”), akár csak a súlyvesztés vagy fogyás/étvágytalanság sem [29]. A kórkép azonnali, agresszív immunszuppresszáns kezelést igényel, a későbbi vasculitises szövődmények (többek között potenciális vakság) elkerülésére.

Diagnosztikus a panaszok jellege és életkori indulás mellett az emelkedett $(>50 \mathrm{~mm} / \mathrm{h}$ ) süllyedés (ESR), illetve a C-reaktív protein (CRP) magas értéke. Az anaemia nem specifikus, de gyakran detektálható eltérés. A temporalis biopszia alátámasztja az óriássejtes arteritis 


\begin{tabular}{|c|c|c|c|}
\hline \multicolumn{2}{|l|}{ A migrén akut rohamterápiája } & \multicolumn{2}{|c|}{ A migrén intervallum- (megelőző) terápiája } \\
\hline NSAID & Evidenciaszint & Vizsgálati szerek & Evidenciaszint \\
\hline Acetilszalicilsav $1000 \mathrm{mg}$ & Erős & Metoprolol 50-200 mg & Erős \\
\hline Ibuprofén $200-800 \mathrm{mg}$ & Erős & Propranolol 40-240 mg & Erős \\
\hline Naproxen $500-1000 \mathrm{mg}$ & Erős & Flunarizin $5-10 \mathrm{mg}$ & Erős \\
\hline Diklofenák 50-100 mg & Erős & Valproát $500-1800 \mathrm{mg}$ & Erős \\
\hline Paracetamol $1000 \mathrm{mg}$ & Erős & Topiramát 25-100 mg & Kevésbé erős \\
\hline Aszpirin + paracetamol + koffein & Erős & Amitriptilin $50-150 \mathrm{mg}$ & Kevésbé erős \\
\hline Metamizol $1000 \mathrm{mg}$ & Mérsékelt & Venlafaxin $75-150 \mathrm{mg}$ & Kevésbé erős \\
\hline Fenazon $1000 \mathrm{mg}$ & Mérsékelt & Bizoprolol 5-10 mg & Mérsékelt \\
\hline Tolfenaminsav $200 \mathrm{mg}$ & Mérsékelt & Gabapentin 1200-1600 mg & Mérsékelt \\
\hline Triptánok & Evidenciaszint & Magnézium $24 \mathrm{mmol}$ & Mérsékelt \\
\hline $\begin{array}{l}\text { Szumatriptán } 25,50,100 \mathrm{mg} \text { per os vagy } \\
25 \mathrm{mg} \text { suppositorium, } 10,20 \mathrm{mg} \text {-os orrspray } \\
\text { vagy } 6 \mathrm{mg} \text { sc - referenciavegyület }\end{array}$ & Mindegyikre erős & $\begin{array}{l}\text { Kandezartán } 16 \mathrm{mg} \\
\text { Lizinopril } 20 \mathrm{mg}\end{array}$ & $\begin{array}{l}\text { Mérsékelt } \\
\text { Mérsékelt }\end{array}$ \\
\hline $\begin{array}{l}\text { Zolmitriptán } 2,5,5 \mathrm{mg} \text { vagy } 2,5 \text { v. } 5 \mathrm{mg} \text {-os } \\
\text { orrpsray }\end{array}$ & & & \\
\hline Naratriptán 2,5 mg & & & \\
\hline Rizatriptán 10 mg & & & \\
\hline Almotriptán 12,5 mg & & & \\
\hline Eletriptán $20,40 \mathrm{mg}$, esetlegesen $80 \mathrm{mg}$ & & & \\
\hline Frovatriptán $2,5 \mathrm{mg}$ & & & \\
\hline
\end{tabular}

NSAID = nemszteroid gyulladáscsökkentő szer

tényét (ezt célszerú azonnal, illetőleg a kezelést követő 2 héten belül kivitelezni), de negatív eredménnyel is járhat (akár az esetek 30\%-ában); negativitása önmagában nem zárja ki a kórkép jelenlétét. A temporalis UH (ún. halojel) igen nagy diagnosztikus érzékenységú, továbbá igen érzékeny MR-angiographiás technikák is rendelkezésre állnak. Szteroidterápia (például $1 \mathrm{~g} /$ nap 3-5 napig) azonnali elkezdése szükséges (ennek hiányában a beteg órák alatt megvakulhat!). Szteroidspóroló ágensként, illetve non-responder esetekben a metotrexát hatékony lehet, továbbá tocilizumab esetében is rendelkezésre állnak evidenciák [29].

\section{Trigeminoautonóm fejfájások}

A trigeminoautonóm fejfájások a primer fejfájások nem gyakori, de igen heves fájdalommal járó formáit ölelik fel [30]. Ezek változó időtartamúak, az igen súlyos fejájás mellett conjuctivabelövelltséggel, orrfolyással járnak, a betegek emiatt első körben gyakran szemészhez, illetőleg fül-orr-gégészhez fordulnak [30].

A cluster fejfájás a leggyakoribb típus a csoporton belül, a lakosság akár 0,1\%-át érintheti, jelentős a férfidomi- nancia. A cluster szó jelentése „csoportosul, összegyúlik”, ami jól tükrözi a típusos cluster fejájás időbeli eloszlását: ismeretlen okból/okokból, a fejfájós periódus jellemzően 1-3 hónapig tart, amit - akár évekig tartó tünetmentes periódus követ. Egy adott fejfájásos roham 15-180 percig tart, jellemzően éjszaka lép fel (de ez nem kizárólagos), a „cluster” periódusban akár napi 4-6 alkalommal. A legerősebb fájdalmak közé sorolják, a fájdalmat gyakran vesekólikához, szülési fájdalomhoz hasonlítják. A fejfájáshoz a fent említett vegetatív tünetek társulnak. Oxigén belélegzése (12-15 1/min) azonnali megkönnyebbülést jelent a beteg számára, így diagnosztikus értékű (egyebekben otthon rohamoldásra általános indikációval a magyar jogszabályok is lehetővé teszik oxigén felírását). Rohamoldásra a triptánok (akár nasalis vagy subcutan formában) hatékonyak lehetnek, nem jól reagáló esetekben szteroid-lökésterápia javasolt $(64 \mathrm{mg}$ legalább 5 napon át, gyomorvédelem és káliumpótlás mellett). Megelőző kezelésként verapamil ajánlott, esetlegesen lítium, topiramát vagy lamotrigin szóba jön [30, 31]. Érdemes tudni, hogy az alkoholfogyasztás cluster fejfájási rohamot provokál. 
A paroxysmalis hemicrania hasonló jellegű fájdalom vegetatív tünetekkel, 2-30 perces idötartamban, naponta többször ismétlődően (akár 10-15×) [30, 31]. Egyenlő nemi eloszlást mutat. Indometacinra egy életen keresztül jól reagál, ez akár diagnosztikus értékü lehet. Emellett még topiramát adása jön szóba $[30,31]$.

A SUNCT- és SUNA-szindrómák mozaikszavak (short-lasting neuralgiform headache attacks with conjunctival injection and tearing/cranial autonomic features), amelyeknél a fejfájás igen rövid ideig tart (másodpercekig általában, maximum néhány percig), de naponta akár százszor ismétlődhet. Saját tapasztalataink a szteroidterápia hatékonysága mellett szólnak, de lamotrigin, topiramát vagy gabapentin is szóba jöhet [32].

A hemicrania continua az előzőekkel szemben hosszú ideje fennálló (>3 hónap), változó intenzitású, de konstans fejfájás, melyet a fenti vegetatív tünetek kísérhetnek. $\mathrm{Az}$ indometacinra adott kiváló terápiás válasz diagnosztikus értékü ebben az esetben is.

Összességében ezek szem körüli fejfájással és a korábban említett autonóm tünetekkel kísért heves, változó időtartamú jellegű fejfájások, melyek - noha döntően csak a fájdalom időtartamában tûnnek eltérőnek, valójában - különböző entitásokat takarnak; ezt támasztja alá az eltérő terápiás paletta is. Az elsőként választandó módszer mindenképpen a koponya-MR az esetleges (az említettekhez hasonló) szekunder fejfájások szürésére. Sajnos a trigeminoautonóm fejfájások ismerete az orvostársadalmon belül még nem teljes, diagnózisuk sokszor megkésve történik, sok felesleges vizsgálat és - a beteg szempontjából - indokolatlanul hosszú szenvedés után [33].

\section{Postherpeses neuralgia}

A kórkép lefolyása során elöször az érintett bőrterületen a látható tünet, vagyis a hólyagok megjelenése előtt néhány nappal fájdalom jelentkezik, amely lehet enyhe és rendkívül erős is. A fájdalom nem minden esetben előzi meg a tünetek kialakulását, előfordul, hogy a bőrtünetekkel pont egy időben vagy esetleg jóval a bőrtünetek lezajlása után alakul ki. Az arcon döntően a trigeminus első ágának megfelelően alakulnak ki a hólyagocskák, illetve ritkábban a hallójáratban, a mastoidalis régió felett jelennek meg. Ritkán a nervus facialis érintettségének következtében perifériás facialis paresis lép fel, ilyenkor a külső hallójárat alsó harmadában láthatók a herpeses eruptiók (Ramsay-Hunt-szindróma), de a perifériás facialis paresisek túlnyomó többségének nem ez áll a hátterében.

Postherpeses neuralgiáról akkor beszélünk, ha a panaszok 3 hónappal a hólyagok megjelenése után is fennállnak, illetőleg ha már a kezdetekben erős neuropathiás karakterü fájdalom lép fel. Sajnálatos módon hazánkban még mindig sok karbamazepinterápia beállítása történik a postherpeses neuralgia esetében, azonban a szer neuropathiás fájdalom kezelésére való alkalmazását (trigeminusneuralgia és egyes ritka neuralgiform fájdalmak kivé- telével) az elemzések egyértelmúen ellenzik egyértelmü bizonyíték hiánya/bizonyított hatástalanság okán [20]. Neuropathiás fájdalom kezelésében használatos szerek alkalmazása javasolt ebben az esetben is, anekdotális adatok szerint az akut fázisban a fájdalom kezelésére alkalmazott amitriptilin csökkenti a postherpeses neuralgia kialakulásának valószínúségét.

\section{Egyéb neuralgiák}

Az alábbi kórképek ritkák, a mindennapi ellátásban jó eséllyel nem is találkozik velük az orvos, de didaktikai szempontból az orofacialis fájdalmak témakörébe tartoznak.

A nyakszirti idegzsába (occipitalis neuralgia) a tarkó hátsó részének, illetve a nyaknak rövid, ütésszerű/nyilalló fájdalmával járó kórkép (a panaszok jellege hasonlít a trigeminus-, illetőleg glossopharyngeus neuralgiához, csak az érintett terület más). A karbamazepin az általunk észlelt néhány esetben jól hatott; ha szükséges, természetesen megpróbálhatók más, neuropathiás fájdalom elleni szerek, esetleges lokális lidokain- vagy botulinustoxin-infiltratio is szóba jöhet [34].

A nervus laryngeus superior neuralgiája a pajzsporctól az állkapocsszeglet felé sugárzó neuralgiform fájdalom, míg az auriculotemporalis neuralgia a parotis-, a praeauricularis és a temporomandibularis terület érintettségével jár. A nervus intermedius neuralgia a belső fül/hallójárat érintettségével jár, gyakran ízérzésváltozás és könnyezési/nyálelválasztási zavarok is kísérik. Vannak a belső szemzugban fellépő neuralgiform fájdalmak is, melyek az orbita, illetôleg az orr vagy a temporomandibularis ízület felé sugároznak ki; néha könnyezéssel, orrfolyással is járhatnak, így szerepet játszhatnak a trigeminoautonóm fejfájások differenciáldiagnosztikájában (például Sluder-neuralgia). Sluder eredeti elképzelése szerint a ganglion sphenopalatinum neuralgiájáról lenne szó, azonban Sluder eredeti leírását kritikusan elemezve nagyon valószínú, hogy az általa észlelt betegek cluster fejfájásban szenvedtek, de megjelenésük irodalmi ritkaság, csupán néhány esettanulmány áll rendelkezésre (Charlin's neuralgia, illetve Sludger's neuralgia). A supraorbitalis neuralgia szintén extrém ritka kórkép, csupán néhány esetközlés található a szakirodalomban.

Összességében a fenti kórképek esetében (ritkaságuk okán) terápiás ajánlások nem léteznek; a karbamazepin, gabapentin, lamotrigin és amitriptilin hatékonynak bizonyulhat, illetóleg lokális analgetikus blokád szóba jöhet $[7,31,34]$.

\section{Kezelési irányelvek krónikus/neuropathiás fájdalom esetén}

A fájdalomcsillapítás az orvosi kezelés egyik központi kérdése. A szervezetünket érő szöveti sérülésről, károsító, ártó hatásokról az ún. nociceptiv fájdalom révén értesü- 
lünk. A másik nagy típus az ún. neuropathiás fájdalom, mely a perifériás vagy a központi idegrendszer primer károsodásának vagy funkciózavarának következtében kialakult krónikus fájdalom. Ezt a fájdalomtípust gyakran aluldiagnosztizálják és tévesen kezelik. Ennek magyarázata részben az orvosképzés hiányossága, részben pedig a háttérben álló komplex patomechanizmus, a változékony tünetek, a diagnosztikus nehézségek és az eltérő kezelési mód. A hagyományos fájdalomcsillapítók a kórkép kezelésében hatástalanok, ezek alkalmazása ilyen esetben gyakran abúzushoz és súlyos mellékhatásokhoz (vérzéses szövődmények, vese- és májkárosodás, vérképzésbeli eltérések stb.) vezet. Neuropathiás fájdalom mellé gyakran társul szorongás, depresszió és alvászavar, melyek a klinikai képet komplikálják, a kezelést nehezítik [35].

A neuropathiás fájdalom kialakulása komplex, jelenleg minden részletében még nem ismert folyamat. A bonyolult perifériás és centrális mechanizmusok közül a legfontosabbak: a membrán-hyperexcitabilitas ectopiás kisülésekkel, a perifériás és centrális szenzitizáció, a gátlómechanizmusok kiesése és a centrális reorganizáció. A folyamatok következtében fokozódik a sejtek ingerlékenysége, megnövekszik receptív területük, és fokozottabban továbbítanak fájdalomimpulzusokat, illetve nem fájdalmas ingerek is fájdalmat váltanak ki. Az adott betegben a különböző jelenségek külön-külön, keveredve, illetőleg időről időre változva jelenhetnek meg [36, 37].

Bonyolítja a képet, hogy gyakori a szövődött pszichopatológia okán az ún. fájdalomszemélyiség kialakulása.

Mindenekelőtt szánjunk kellő időt a betegekre, hagyjuk, hogy legalábbis a terápia első néhány percében elmondja panaszait, s csak utána próbáljuk a beszélgetést célzottabban irányítani. Fájdalomcentrumokban végzett felmérések szerint a betegek mintegy $80 \%$-a 2 percen belül befejezi első gondolatait, ha hagyjuk, míg a vizsgáló spontán átlagosan 23 másodperc múlva szakítja ezt félbe. A kommunikáció javítása, a betegre több idő szánása jelentősen javítja a kezelés effektusát [38].

A beteg pszichés statusa, esetleges emocionális instabilitása egyrészt a kórelőzményben igen gyakori pszichiátriai megbetegedések következménye, de ehhez hozzájárul a krónikus fájdalom következtében létrejött agyi atrófia és centrális szenzibilitásváltozások is, vagyis - legalábbis részben, de - lehetséges, hogy teljesen organikus magyarázata van. Ráadásul felmerül annak lehetősége, hogy bizonyos genetikai prediszpozíció (a katechol-Ometiltranszferáz [COMT]-gén polimorfizmusa, illetve a voltage-gated sodium-channel [feszültségfüggő nátriumcsatorna] „IX $\alpha$ subunit [SCN9A]” mutációja) is szerepet játszhat a krónikus fájdalom és a fájdalomszemélyiség kialakulásában.

Önmagában a pszichiátriai kezelés nem elég, a terapeuták többsége nem rendelkezik ilyen irányú képzéssel/ szemlélettel; ráadásul a pszichiátriában alkalmazott gyógyszerek túlnyomó többsége nem rendelkezik érdemi fájdalomcsillapító hatással, illetve neuropathiás fájdalom elleni effektivitással.
Mindenképpen mondjuk el a betegnek, hogy a kezelés során alkalmazott szerek hatásának minimális kialakulási ideje 2-3 hét, de a megfelelő hatékonyság kialakulásához akár 2-3 hónapra szükség lehet. Sok esetben az azonnali fájdalomcsillapító effektus elmaradása miatt kerül sor gyógyszerelhagyásra, illetőleg a terapeuta ezek alapján terápiarezisztens fájdalom miatt továbbreferálja a beteget esetleges sebészeti ellátás céljából [39]. Ezt azt átmeneti periódust, míg a szerek hatása kialakul, át lehet hidalni szintetikus opiátszármazék adekvát dózisú alkalmazásával (például Tramadolor).

A gyakorlatban 3 nagy gyógyszercsoport jön szóba a krónikus (neuropathiás) fájdalom kezelésében első vonalbeli szerként: a triciklusos antidepresszánsok (TCA), a kettős, szerotonin-noradrenerg rendszerre is ható antidepresszánsok (SNRI-k), illetőleg a gamma-amino-vajsav-analóg (GABA-erg) szerek, míg másodvonalbeli szerként az opioidok szerepelnek [40].

Hatékonyságuk lehetséges magyarázata az, hogy a szervezet ún. „belsődleges” fájdalomcsillapító mechanizmusait aktiválják. Az utóbbi évtizedek egyik legfontosabb kutatási eredménye a neurobiológiában, hogy a fájdalom csillapításában az alsó agytörzs több sejtcsoportjának neuronjai is részt vesznek. A szabályozórendszer afferens felszálló szárát a spinomesencephalicus pálya képezi. A gerincvelő hátsó szarvától ipsilateralisan felszálló rostok a periaquaeductalis szürkeállomány (PAG) enkefalin- és dinorfintartalmú idegsejtjein végződnek. A felsorolt szerek a fenti jelátviteli útvonalakban több ponton is hatással bírnak, a belső fájdalomcsillapító utak aktiválása révén alakulhat ki antinociceptiv mechanizmusuk [36, 37, 40].

A hazánkban elérhető TCA-k közé tartozik az amitriptilin és a klomipramin. Noha eredetileg antidepreszszáns szernek fejlesztették ki őket, a kórkép kezelésében jelentőségük már korlátozott, de markáns neuropathiás fájdalom elleni hatékonysággal rendelkeznek. Igen kedvező az áruk, néhány száz forintos havi költséget jelentenek a betegnek még normatív jogcímen is felírva (amit akár háziorvosuk is megtehet). Leggyakoribb mellékhatásaik az álmosság mellett (melyet kihasználunk az alvásjavító hatás céljából, ezt az aktuális európai ajánlások is támogatják az insomnia kezelésében - értelemszerün este adandók mindenképpen) a szájszárazság, szédülékenység és székrekedés. E mellékhatásaik (a szájszárazság kivételével) általában enyhék és átmenetiek, de ha - ritkán - súlyos formában jelentkeznek, a beteg a kezelést megszakítja. Glaucoma, illetve friss szívinfarktus, szívritmuszavar esetén alkalmazásuk kerülendő, ekkor a gyógyszer szedése veszélyes is lehet $[40,41]$. Antidepresszáns (SSRI, SNRI), illetve monoamin-oxidáz (MAO)-gátló kezeléssel együttesen nem adhatók a potenciális szerotoninszindróma lehetősége miatt.

A másik nagy gyógyszercsoportot az SNRI-k képezik, melyek közé a venlafaxin, a duloxetin és a mirtazapin tartozik, az első kettő esetében rendelkezünk meggyőző evidenciákkal [40]. Markáns antidepresszáns hatásukat 
használjuk ki hangulatzavarral szövődött fájdalom esetében, továbbá megemlítendő, hogy a szorongásos kórképek első vonalbeli szereiként szerepelnek, a hazánkban alkalmazott benzodiazepinkezeléssel ellentétben [40, 42]. Venlafaxin normatív jogcímen felírható akár alapellátásban is kedvező áron, míg a duloxetin esetében ez nem mondható el, általános indikációval több ezer forintos ára miatt nem mindenki engedheti meg magának.

Mellékhatásaik általában enyhék, a legtöbb esetben enyhe dyspepsia lép fel, de ritkán előfordulhat súlyos hányinger, hányás, mellkasi fájdalom: ilyenkor a kezelés megszakítása szükséges. Fiatal beteg esetében gondoljunk az impotencia lehetőségére is.

A gabapentin és a pregabalin az inhibitorikus tulajdonságú neurotranszmitter, a gamma-amino-vajsav (GABA) strukturális analógjai, melyeket eredetileg antiepileptikumnak fejlesztettek ki. Pontos hatásmechanizmusuk nem teljesen ismert, feltehetőleg a feszültségfüggő kalciumcsatornák $\alpha 2 \delta$-alegységéhez kötődnek, ezáltal szabályozva a csatorna múködését és a neurotranszmitterek szekrécióját [43-45]. Ezáltal befolyásolja a hátsó szarvi neuronok múködését, ami a fájdalom centrális szenzitizációjában játszik szerepet [45]. Valószínúleg hatást fejt ki az N-metil-D-aszparaginát (NMDA)-receptorokon és nátriumcsatornákon keresztül, továbbá befolyásolja a monoaminerg és opiáttranszmissziót is [45].

Összetett hatásmechanizmusuknak köszönhetően igen hatékonyak a neuropathiás fájdalom csökkentésében, továbbá vesén keresztüli ürülésüknek köszönhetően interakciós potenciáljuk alacsony. Hazánkban kedvezményesen írhatók fel fájdalmas diabeteses neuropathiában, egyéb, fájdalommal járó kórképekben, illetve nem diabeteses betegekben támogatással nem írhatók fel; emellett normatív jogcímen áruk igen borsos. Epilepszia kezelésére a gabapentin rendelkezik törzskönyvi indikációval (és támogatással) hazánkban, míg a pregabalin nem. A pregabalin hatékony szer generalizált szorongás ellen, de hazánkban ilyen indikációval használata nem engedélyezett (de diabeteses betegben, fóleg ha a fájdalom mellett szorongás áll az előtérben, célszerú ezt kihasználni) [42].

Mellékhatásaik közül kiemelendő a szédülés, mely óvatos dózistitrálással megelőzhető, továbbá esetleges arc- és bokaödéma fellépése [40].

Végezetül pedig másodvonalbeli szerként (noha a korábbi orvosi irodalom a neuropathiás fájdalmat morfinrezisztens fájdalomként írta le) az opiátok is szóba jönnek, de potenciálisan súlyos mellékhatásaik és az addikció lehetősége alkalmazásuknak gátat szab [40]. Alkalmazásuk szóba jöhet átmenetileg első vonalbeli szerként is, míg a fent említett gyógyszerek dózisának feltitrálása történik.

Nem megfelelő hatékonyság esetén opiátszármazék bármelyik szer mellé kombinálható, illetőleg terápiarezisztens esetben lehetőség van TCA-GABAerg szer, illetőleg SNRI-GABAerg szer kombinációjára is; TCA és SNRI együtt a potenciálisan letális kimenetelű szerotoninszindróma eshetősége miatt nem alkalmazható [40].
A korábban alkalmazott lokális analgetikus blokádokat a fenti modern orális szerek csaknem teljesen kiszorították a mindennapi gyakorlatból a krónikus fájdalom kezelésében, azonban bizonyos esetekben alkalmazásuk szóba jöhet. Occipitalis neuralgia, illetőleg egyéb, ritkább neuralgiák, valamint temporomandibularis ízületi diszfunkció okozta arcfájdalom esetében lidokainos infiltratio szóba jöhet, de erős evidenciák jelenleg nem állnak rendelkezésre [46]. A botulinustoxin-kezelés egyértelmúen hatékony a krónikus migrén kezelésében, és egyéb krónikus/neuropathiás fájdalmak kezelésében is szerepe lehet, de meggyőző bizonyítékok még nem állnak rendelkezésre [47].

\section{Következtetés}

A krónikus arcfájdalom kezelése nagy kihívás elé állítja mind a gyógyítót, mind a beteget. A kórkép kezelésében új szemléletmód szükséges az utóbbi évek neurobiológiai kutatási eredményei alapján. Mindenképpen többszakmás konszenzusokra, munkacsoportokra van szükség (multidisciplinary team) a kórképek sokszínúsége és a konkomittáns pszichopatológia okán. Az eddigi szemléletmód megváltoztatásra szorul, elkerülvén a felesleges diagnosztikus és mútéti beavatkozásokat, melyek a beteg állapotát nem feltétlenül rontják, de pszichés megterhelését mindenképpen fokozzák.

Anyagi támogatás: A szerzők anyagi támogatásban nem részesültek.

Szerzői munkamegosztás: A szerzők egyenlő mértékben vettek részt az anyaggyüjtésben, az adatok feldolgozásában és a kézirat megírásában. A cikk végleges változatát valamennyi szerző elolvasta és jóváhagyta.

Érdekeltségek: A szerzőknek a kézirattal kapcsolatban nincsenek érdekeltségeik.

\section{Irodalom}

[1] Aggarwal VR, McBeth J, Zakrzewska JM, et al. The epidemiology of chronic syndromes that are frequently unexplained: do they have common associated factors? Int J Epidemiol. 2006; 35 : 468-476.

[2] Beecroft EV, Durham J, Thomson P. Retrospective examination of the healthcare 'journey' of chronic orofacial pain patients referred to oral and maxillofacial surgery. Br Dent J. 2013; 214 : E12.

[3] Komoly S. Chronic pain and its consequences. [A krónikus fájdalom következményei.] Korszerü Kaleidoszkóp 2017; 3(2): 3-7. [Hungarian]

[4] Spadliński Ł, Cecot T, Majos A, et al. The epidemiological, morphological, and clinical aspects of the cervical ribs in humans. Biomed Res Int. 2016; 2016: 8034613.

[5] DN4 Questionnaire. [DN4 kérdőív.] Available from: http:// neurology.pote.hu/neuro/modules/nyomtatvanyok/dn4/ dn4kerdoiv.pdf [accessed: March 8, 2019]. [Hungarian] 
[6] Aggarwal VR, Lunt M, Zakrzewska JM, et al. Development and validation of the Manchester orofacial pain disability scale. Community Dent Oral Epidemiol. 2005; 33: 141-149.

[7] Okeson JP, de Leeuw R. Differential diagnosis of temporomandibular disorders and other orofacial pain disorders. Dent Clin North Am. 2011; 55: 105-120.

[8] Siccoli MM, Bassetti CL, Sándor PS. Facial pain: clinical differential diagnosis. Lancet Neurol. 2006; 5: 257-267.

[9] Mathew S, Thangavel B, Mathew CA, et al. Diagnosis of cracked tooth syndrome. J Pharm Bioallied Sci. 2012; 4(Suppl 2): S242S244.

[10] Kaur A, Dhillon N, Singh S, et al. Orofacial pain: an update on differential diagnosis. J Med Res. 2017; 3: 93-98.

[11] Zakrzewska JM. Multi-dimensionality of chronic pain of the oral cavity and face. J Headache Pain 2013; 14: 37.

[12] Feller L, Fourie J, Bouckaert M, et al. Burning mouth syndrome: aetiopathogenesis and principles of management. Pain Res Manag. 2017; 2017: 1926269.

[13] Wilson KF, Meier JD, Ward PD. Salivary gland disorders. Am Fam Physician 2014; 89: 882-888.

[14] Jääskeläinen SK. Pathophysiology of primary burning mouth syndrome. Clin Neurophysiol. 2012; 123: 71-77.

[15] Ritchie A, Kramer JM. Recent advances in the etiology and treatment of burning mouth syndrome. J Dent Res. 2018; 97: 11931199.

[16] Khan M, Nishi SE, Hassan SN, et al. Trigeminal neuralgia, glossopharyngeal neuralgia, and myofascial pain dysfunction syndrome: an update. Pain Res Manag. 2017; 2017: 7438326.

[17] Cruccu G, Gronseth G, Alksne J, et al. AAN-EFNS guidelines on trigeminal neuralgia management. Eur J Neurol. 2008; 15: 1013-1028.

[18] Barker FG 2nd, Jannetta PJ, Bissonette DJ, et al. The long-term outcome of microvascular decompression for trigeminal neuralgia. N Engl J Med. 1996; 334: 1077-1083.

[19] Zhang GQ, Meng Y. Oral and craniofacial manifestations of multiple sclerosis: implications for the oral health care provider. Eur Rev Med Pharmacol Sci. 2015; 19: 4610-4620.

[20] Wiffen PJ, Derry S, Moore RA, et al. Carbamazepine for chronic neuropathic pain and fibromyalgia in adults. Cochrane Database Syst Rev. 2014; (4): CD005451.

[21] Meng F, Peng K, Yang JP, et al. Botulinum toxin-A for the treatment of neuralgia: a systematic review and meta-analysis. J Pain Res. 2018; 11: 2343-2351.

[22] Tinastepe N, Oral K. Neuropathic pain after dental treatment. Agri 2013; 25: 1-6.

[23] Headache Classification Committee of the International Headache Society (IHS). The International Classification of Headache Disorders, 3rd edn. Cephalalgia 2018; 38: 1-211.

[24] Yoon MS, Mueller D, Hansen N, et al. Prevalence of facial pain in migraine: a population-based study. Cephalalgia 2010; 30: 92-96.

[25] Schiffman E, Ohrbach R, Truelove E, et al. Diagnostic Criteria for Temporomandibular Disorders (DC/TMD) for Clinical and Research Applications: recommendations of the International RDC/TMD Consortium Network and Orofacial Pain Special Interest Group. J Oral Facial Pain Headache 2014; 28: 6-27.

[26] France K, Sollecito TP. How evidence-based dentistry has shaped the practice of oral medicine. Dent Clin North Am. 2019; 63: 83-95.

[27] Butts R, Dunning J, Pavkovich R, et al. Conservative management of temporomandibular dysfunction: a literature review with implications for clinical practice guidelines (Narrative review part 2). J Body Mov Ther. 2017; 21: 541-548.

[28] Häggman-Henrikson B, Alstergren P, Davidson T, et al. Pharmacological treatment of oro-facial pain - health technology assessment including a systematic review with network meta-analysis. J Oral Rehabil. 2017; 44: 800-826.
[29] Winkler A, True D. Giant cell arteritis: 2018 review. Mo Med. 2018; 115: 468-470.

[30] May A. Diagnosis and clinical features of trigemino-autonomic headaches. Headache 2013; 53: 1470-1478.

[31] Eller M, Goadsby PJ. Trigeminal autonomic cephalalgias. Oral Dis. $2016 ; 22$ : $1-8$.

[32] Trauninger A, Alkonyi B, Kovács N, et al. Methylprednisolone therapy for short-term prevention of SUNCT syndrome. Cephalalgia 2010; 30: 735-739.

[33] Feher G, Fejes E, Gombos K, et al. Characteristics of patients referred to a primary headache clinic. [Fejfájás centrumunkba referált betegeink előzményeinek áttekintése.] Cephalalgia Hung. 2018; 28: 9. [Hungarian]

[34] O'Neill F, Nurmikko T, Sommer C. Other facial neuralgias. Cephalalgia 2017; 37: 658-669.

[35] Kiss G. A holistic approach to neuropathic pain. [A neuropathiás fájdalom holisztikus megközelítése.] LAM 2009; 19: 185-190. [Hungarian]

[36] Komoly S, Palkovits M. Practical neurology and neuroanatomy. 4th improved, revised, expanded edition. [Gyakorlati neurológia és neuroanatómia. 4. javított, átdolgozott, bővített kiadás.] Medicina Könyvkiadó, Budapest, 2018. [Hungarian]

[37] Palkovits $M$. The brain and the pain: neurotransmitters and neuronal pathways of pain perception and response. [Az agy és a fájdalom: az érzékelés és a válasz agypályái és transzmitterei.] Orv Hetil. 2000; 141: 2231-2239. [Hungarian]

[38] Marvel MK, Epstein RM, Flowers K, et al. Soliciting the patient's agenda: have we improved? JAMA 1999; 281: 283-287.

[39] Robinson JD, Heritage J. Physicians' opening questions and patients' satisfaction. Patient Educ Couns. 2006; 60: 279-285.

[40] Deli G, Bosnyak E, Pusch G, et al. Diabetic neuropathies: diagnosis and management. Neuroendocrinology 2013; 98: 267280.

[41] Riemann D, Baglioni C, Bassetti C, et al. European guideline for the diagnosis and treatment of insomnia. J Sleep Res. 2017; 26: 675-700.

[42] Bandelow B, Sher L, Bunevicius R, et al., WFSBP Task Force on Mental Disorders in Primary Care, WFSBP Task Force on Anxiety Disorders, OCD and PTSD. Guidelines for the pharmacological treatment of anxiety disorders, obsessive-compulsive disorder and posttraumatic stress disorder in primary care. Int $\mathrm{J}$ Psychiatry Clin Pract. 2012; 16: 77-84.

[43] Rajna P, Szíjártó E. Efficacy, safety and effect on the quality of life of gabapentin in adult epilepsy - Results of a prospective openlabel quasi naturalistic Hungarian multicenter study (phase human-IV). [A gabapentin hatékonysága, biztonságossága és az életminőségre gyakorolt hatása felnőttkori epilepsziában - Nyílt, prospektív, naturalisztikus elemeket tartalmazó, humán, IV. fázisú, hazai, többközpontú vizsgálat értékelése.] Ideggyógy Szle. 2006; 59: 361-372. [Hungarian]

[44] Chang CY, Challa CK, Shah J, et al. Gabapentin in acute postoperative pain management. Biomed Res Int. 2014; 2014: 631756.

[45] Kanner AM, Ashman E, Gloss D, et al. Practice guideline update summary: efficacy and tolerability of the new antiepileptic drugs. II: Treatment-resistant epilepsy. Epilepsy Curr. 2018; 18: 269278.

[46] Curatolo M. Regional anesthesia in pain management. Curr Opin Anaesthesiol. 2016; 29: 614-619.

[47] Sandrini G, De Icco R, Tassorelli C, et al. Botulinum neurotoxin type A for the treatment of pain: not just in migraine and trigeminal neuralgia. J Headache Pain 2017; 18: 38.

(Fehér Gergely dr., Pécs, Nyár u. 8., 7624 e-mail: feher.gergely@pte.hu) 